\title{
Unit of Spread Rate of Substance
}

National Cancer Institute

\section{Source}

National Cancer Institute. Unit of Spread Rate of Substance. NCI Thesaurus. Code C67280.

An indication of the type of unit of measure being used to express a spread rate of a substance. 